\title{
Treadmill exercise alleviates depressive symptoms in rotenone-induced Parkinson disease rats
}

\author{
Mal-Soon Shin', Tae-Woon Kim², Jae-Min Lee' ${ }^{2}$ Yun-Hee Sung ${ }^{3}$, Baek-Vin Lim,* \\ ${ }^{1}$ School of Global Sport Studies, Korea University, Sejong, Korea \\ ${ }^{2}$ Department of Physiology, College of Medicine, Kyung Hee University, Seoul, Korea \\ ${ }^{3}$ Department of Physical Therapy, College of Health Sciences, Kyungnam University, Changwon, Korea \\ ${ }^{4}$ Division of Leisure \& Sports Science, Department of Exercise Prescription, Dongseo University, Busan, Korea
}

Parkinson disease (PD) is characterized by selective loss of the dopaminergic neurons. The symptoms of depression following PD are closely associated with reduced activity of the serotonergic system in the dorsal raphe. We explored the anti-depressive effect of exercise and its possible mechanism using the rotenone-induced $P D$ rats. PD rats were induced by subcutaneously injection with rotenone for 14 days. The rats in the exercise groups were made to run on a treadmill for 30 min once a day during 14 consecutive days. Forced swimming test, immunohistochemistry for serotonin (5-hydroxytryptamine, 5-HT), tryptophan hydroxylase (TPH), and western blot for serotonin ${ }_{1 \mathrm{~A}}\left(5-\mathrm{HT}_{1 \mathrm{~A}}\right)$ receptor were conducted. Injection of rotenone induced PD rats. PD rats showed depressive state and treadmill exercise ameliorated this depressive state.
5- $\mathrm{HT}, \mathrm{TPH}$, and $5-\mathrm{HT}_{1 \mathrm{~A}}$ receptor expressions in the dorsal raphe were suppressed by rotenone injection and treadmill exercise increased the expressions of $5-\mathrm{HT}, \mathrm{TPH}$, and $5-\mathrm{HT}_{1 \mathrm{~A}}$ receptor in the rotenone-injected rats. The present results show that treadmill exercise ameliorated depressive symptoms in the rotenone-induced PD rats. The antidepressive effect of treadmill exercise might be ascribed to the enhancement of serotonergic function through upregulation of $5-\mathrm{HT}_{1 \mathrm{~A}}$ expression in the dorsal raphe.

Keywords: Parkinson disease, Treadmill exercise, Rotenone, Serotonin, Serotonin ${ }_{1 \mathrm{~A}}$ receptor

\section{INTRODUCTION}

Parkinson disease (PD) is characterized by selective loss of the dopaminergic neurons in the substantia nigra pars compacta and striatum. Intracytoplasmic inclusions, called Lewy bodies, in the remaining dopaminergic neurons is the hallmark of pathophysiology of $\mathrm{PD}$, and resting tremor, rigidity, bradykinesia, and gait disturbance are the characteristics of PD patients (Blesa et al., 2012; Varçin et al., 2012). In addition to motor dysfunction, depression is the most frequent psychiatric complication in PD patients, and depression is one of the most important factors reducing quality of life of PD patients (Aarsland et al., 2011).

Depression is associated with functional impairment of serotonergic neurotransmitter system, such as serotonin (5-hydroxy- tryptamine, 5-HT), tryptophan hydroxylase (TPH), and 5-HT transporters, which are involved in the regulation of mood (Christiansen et al., 2007). Of these, 5-HT is an important neurotransmitter in the many neuropsychiatric disorders, such as schizophrenia, depression, anxiety neuromodulator in the mammalian brain (Graeff, 1997; Lucki, 1998). As such, The TPH gene, coding for the rate-limiting enzyme in the biosynthesis of 5-HT, might be involved in pathogenesis events involving dysfunction of the 5-HT system. Thus, TPH is one of the major candidate genes for psychiatric and behavioral disorders, in particular, depression (Roy et al., 1999). Tryptophan depletion also increases symptom severity in depression patients through down-regulation of 5-HT biosynthesis (Neumeister et al., 2004; Ruhé et al., 2007). The symptoms of depression following PD are closely associated with re-
${ }^{*}$ Corresponding author: Baek-Vin Lim (D) http://orcid.org/0000-0003-4017-573X Division of Leisure \& Sports Science, Department of Exercise Prescription, Dongseo University, 47 Jurye-ro, Sasang-gu, Busan 47011, Korea Tel: +82-51-320-1887, Fax: +82-51-320-1945, E-mail: todd64@naver.com Received: February 2, 2017 / Accepted: April 18, 2017
This is an Open Access article distributed under the terms of the Creative Commons Attribution Non-Commercial License (http://creativecommons.org/licenses/by-nc/4.0/) which permits unrestricted non-commercial use, distribution, and reproduction in any medium, provided the original work is properly cited. 
duced activity of the serotonergic system (Kish et al., 2008). Reduction of serotonin and its metabolites was reported in brains of PD patients (Kish et al., 2008). Serotonergic neurons are closely correlated with depression (Brook and Pavese, 2011).

5-HT receptors are divided into 14 subtypes (Barnes and Sharp, 1999). Of receptor subtypes, serotonin ${ }_{1 \mathrm{~A}}\left(5-\mathrm{HT}_{1 \mathrm{~A}}\right)$ receptor, a $\mathrm{G}$ protein-coupled receptor, plays a major role in the process of psychiatric disorders (Savitz et al., 2009). Positive correlation was appeared between depression and binding to the serotonin transporter and 5-HT $\mathrm{T}_{1 \mathrm{~A}}$ receptor (Boileau et al., 2008; Brooks and Pavese, 2011). 5- $\mathrm{HT}_{1 \mathrm{~A}}$ receptor dysfunction causes depression (Leitch et al., 2003), and 5-HT $\mathrm{T}_{1 \mathrm{~A}}$ receptor is implicated in the progression of psychiatric disorders (Savitz et al., 2009).

Exercise is known to exert antidepressive effect on depression patients (Strawbridge et al., 2002) as well as on animal model of depression (Shin et al., 2017b). The purpose of this study is to explore the antidepressive effect of treadmill exercise and its possible mechanism using the rotenone-induced PD rats.

\section{MATERIALS AND METHODS}

\section{Animals and treatments}

Male Sprague-Dawley rats, weighing $250 \pm 10 \mathrm{~g}$ (9 weeks of age), were used in this experiment. They were kept in a room with controlled temperature $\left(20^{\circ} \mathrm{C} \pm 2^{\circ} \mathrm{C}\right)$ under a 12 -hr light $/ 12$ hr dark cycle. The animals were allowed free access to food and water. All animal experimental procedures conformed to the regulations stipulated by the National Institutes of Health and the guidelines of the Korean Academy of Medical Science. The animals were randomly divided into four groups ( $\mathrm{n}=10$ in each group): the control group, the control and treadmill exercise group, the rotenone-injected group, and the rotenone-injected and treadmill exercise group.

\section{PD animal model}

PD rats were induced, according to the previously described method (Shin et al., 2017a). Rotenone was purchased from Sigma Chemical Co. (St. Louis, MO, USA). The rats in the rotenone-injected groups were injected subcutaneously with rotenone (3.0 $\mathrm{mg} / \mathrm{kg}$ ) for 14 days, dissolved into dimethyl sulfoxide. The rats in the control group were injected subcutaneously with dimethyl sulfoxide daily for the same duration.

\section{Exercise protocol}

The animals in the exercise groups were forced to run on a mo- torized treadmill for 30 min once a day during 14 consecutive days. The exercise load consisted of running at a speed of $2 \mathrm{~m} / \mathrm{min}$ for the first $5 \mathrm{~min}, 3 \mathrm{~m} / \mathrm{min}$ for the next $5 \mathrm{~min}$, and then $4 \mathrm{~m} /$ $\min$ for the last $20 \mathrm{~min}$.

\section{Forced swimming test}

In order to evaluate depression severity, we performed a modified forced swimming test (FST), according to the previously described method (Shin et al., 2017b). After cessation of exercise, the rats conducted a pre-test for $15 \mathrm{~min}$ to eliminate the acute stress by water and to adapt the animals to the water. Twenty-four $\mathrm{hr}$ after the pre-test, the rats were tested for $6 \mathrm{~min}$. The animals were placed individually into the glass cylinder $20 \mathrm{~cm}$ in diameter and $90 \mathrm{~cm}$ in height, filled with water to a height of $75 \mathrm{~cm}$. The temperature of the water was adjusted to $25^{\circ} \mathrm{C} \pm 1^{\circ} \mathrm{C}$. During the test session, the climbing time and immobility time were analyzed using a Smart version 2.5 video tracking system (Panlab, Barcelona, Spain). Immobility was defined to occur when no additional activity was observed other than the actions needed to keep the rat's head above the water. Climbing was defined to occur when the rat was in an active vertical motion with its forelegs above the water level.

\section{Tissue preparation}

After FST, the rats were deeply anesthetized with Zoletil 50 anesthesia ( $1 \mathrm{mg} / \mathrm{kg}$, intraperitoneally; Vibac Laboratories, Carros, France). After complete anesthesia, the rats were transcardially perfused with 0.05-M phosphate-buffered saline (PBS), followed by $4 \%$ paraformaldehyde in $0.5-\mathrm{M}$ sodium phosphate buffer at $\mathrm{pH}$ 7.4. The brain was removed, postfixed in the same fixative overnight, and transferred to a $30 \%$ sucrose solution for cryoprotection. Serial $40-\mu \mathrm{m}$-thick coronal sections were cut with a freezing microtome (Leica, Nussloch, Germany).

\section{Immunohistochemistry for 5-HT and TPH}

Immunohistochemistry for 5-HT and TPH was performed, according to the previously described method (Shin et al., 2017b). An average of eight sections was selected in each brain region spanning from Bregma -7.30 to $-8.00 \mathrm{~mm}$. The sections were incubated in PBS for 10 min and they were next washed three times with PBS. The sections were then incubated in $1 \% \mathrm{H}_{2} \mathrm{O}_{2}$ for 30 $\mathrm{min}$, and then they were incubated overnight with rabbit anti-5HT antibody (Oncogene Research Product, Cambridge, UK) at a dilution of 1:500 or with mouse anti-TPH antibody (Oncogene Research Product) at a dilution of 1:500. The sections were incu- 
bated for $1 \mathrm{hr}$ with biotinylated anti-rabbit secondary antibody or with anti-mouse secondary antibody (Vector Laboratories, Burlingame, CA, USA), and they were subsequently incubated with avidin-biotin-peroxidase complex (Vector Laboratories) for $1 \mathrm{hr}$ at room temperature. Immunoreactivity was visualized by incubating the sections in a solution consisting of $0.05 \% 3,3^{\prime}$-diaminobenzidine and $0.01 \% \mathrm{H}_{2} \mathrm{O}_{2}$ in $50-\mathrm{mM}$ Tris-buffer $(\mathrm{pH}, 7.6)$ for approximately $3 \mathrm{~min}$. The sections were finally mounted on gelatin-coated glass slides. The slides were air-dried overnight at room temperature, and the coverslips were mounted using Permount (Thermo Fisher Scientific Inc., Waltham, MA, USA).

\section{Western blot analysis}

Western analysis was performed, according to the previously described method (Shin et al., 2017b). Dorsal raphe tissues were dissected. Sample tissues were stored at $-70^{\circ} \mathrm{C}$ until analysis. Sample tissues were lysed in ice-cold lysate buffer containing $50-\mathrm{mM}$ HEPES (pH 7.5), 150-mM NaCl, $10 \%$ glycerol, $1 \%$ Triton $\mathrm{X}-100,1.5-\mathrm{mM}$ magnesium chloride hexahydrate, 1-mM ethyleneglycol-bis-( $\beta$-aminoethyl ether)-N, $\mathrm{N}^{\prime}$-tetraacetic acid, 1-mM phenylmethylsulfonyl fluoride, $2-\mu \mathrm{g} / \mathrm{mL}$ leupeptin, $1-\mu \mathrm{g} /$ $\mathrm{mL}$ pepstatin, $1-\mathrm{mM}$ sodium orthovanadate, and $100-\mathrm{mM}$ sodium fluoride, after which the mixture was incubated for $30 \mathrm{~min}$ at $4^{\circ} \mathrm{C}$. The tissues debris was then removed by microcentrifugation followed by quick freezing of the supernatant. The protein concentration was measured using a Bio-Rad colorimetric protein assay kit (Bio-Rad, Hercules, CA, USA). Protein of $30 \mu \mathrm{g}$ was separated on sodium dodecyl sulfate-polyacrylamide gels and transferred onto a nitrocellulose membrane (Whatman, Clifton, NJ, USA). Rabbit anti-5-HT ${ }_{1 \mathrm{~A}}$ antibody (1:1,000; Abcam, Cambridge, UK) were used as a primary antibody. Horseradish peroxidase-conjugated anti-rabbit antibody (1:3,000; Vector Laboratories) was used to probe for $5-\mathrm{HT}_{1 \mathrm{~A}}$. Band detection was performed using the enhanced chemiluminescence detection system (Santa Cruz Biotechnology, Santa Cruz, CA, USA). The bands were quantified using an Image-Pro Plus computer-assisted image analysis system (Media Cybernetics Inc., Bethesda, MD, USA).

\section{Statistical analysis}

All data were analyzed using IBM SPSS Statistics ver. 23.0 (IBM Co., Armonk, NY, USA). The data were expressed as the mean \pm standard error of the mean. For the comparison among the groups, One-way analysis of variance and Duncan post hoc test were performed with $P<0.05$ as an indication of statistical significance.
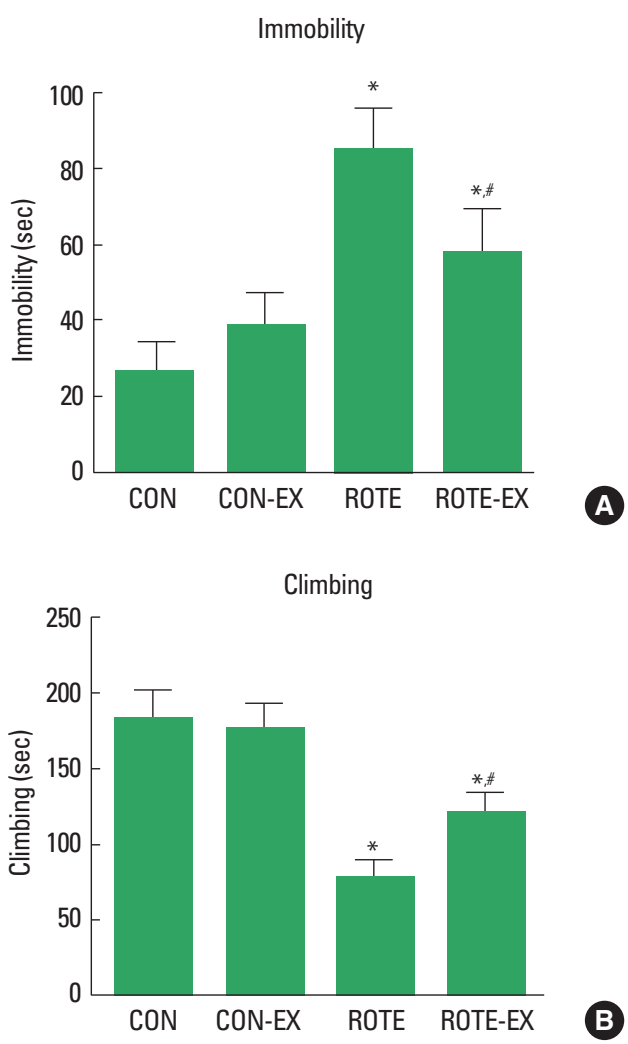

Fig. 1. Effect of treadmill exercise on immobility and climbing time in the forced swimming test. (A) Immobility time. (B) climbing time. CON, control group; CON-EX, control and treadmill exercise group; ROTE, rotenone-injected group; ROTE-EX, rotenone injected and treadmill exercise group. Data are presented as the means \pm standard error of the mean. ${ }^{*} P<0.05$ compared to the control group. ${ }^{\#} P<0.05$ compared to the rotenone-injected group.

\section{RESULTS}

\section{Effect of treadmill exercise on immobility and climbing time in the forced swim test}

The immobility time and climbing time in the FST are presented in Fig. 1. The immobility time was increased by injection of rotenone $(P<0.05)$ and treadmill exercise decreased immobility time in the rotenone-injected rats $(P<0.05)$. The climbing time was decreased by injection of rotenone $(P<0.05)$ and treadmill exercise increased climbing time in the rotenone-injected rats $(P<0.05)$.

\section{Effect of treadmill exercise on 5-HT expression in the dorsal raphe}

Photomicrographs of 5-HT-positive cells in the dorsal raphe are presented in Fig. 2. The number of TPH-positive cells in the dorsal raphe was $287.10 \pm 18.37 /$ section in the control group, 

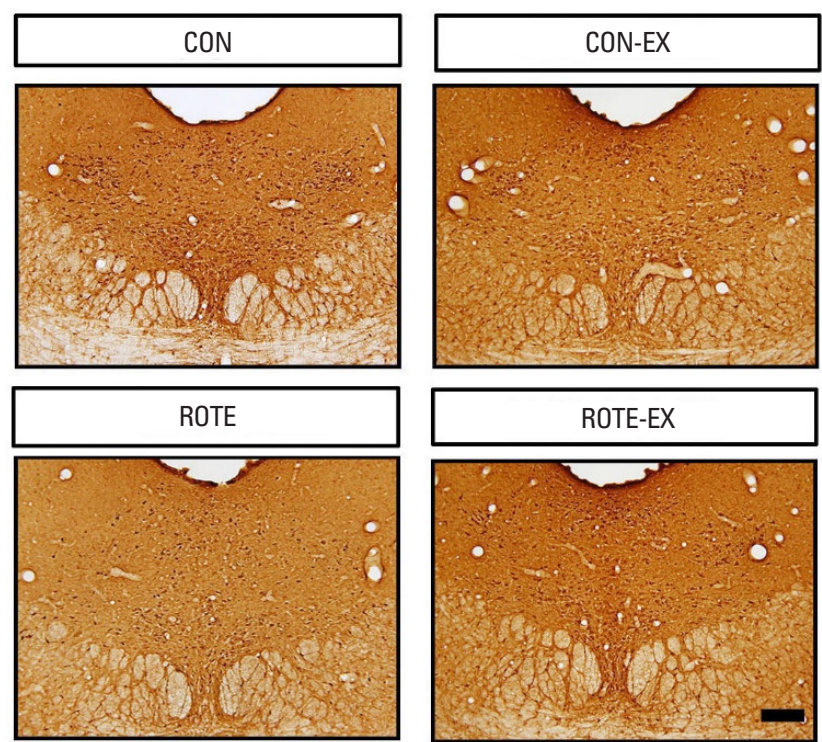

Fig. 2. Photomicrographs showing 5-hydroxytryptamine (5-HT) expressions in the dorsal raphe. The scale bar is $100 \mu \mathrm{m}$. CON, control group; CON-EX, control and treadmill exercise group; ROTE, rotenone-injected group; ROTE-EX, rotenone injected and treadmill exercise group.

$285.30 \pm 16.89 /$ section in the control and treadmill exercise group, $217.40 \pm 18.55 /$ section in the rotenone-injected group, $283.10 \pm 14.80$ /section in the rotenone-injected and treadmill exercise group. 5-HT expression in the dorsal raphe was decreased by injection of rotenone $(P<0.05)$ and treadmill exercise increased 5-HT expression in the rotenone-injected rats $(P<0.05)$.

\section{Effect of treadmill exercise on TPH expression in the dorsal raphe}

Photomicrographs of TPH-positive cells in the dorsal raphe are presented in Fig. 3. The number of TPH-positive cells in the dorsal raphe nuclei was $474.90 \pm 17.13 /$ section in the control group, $496.00 \pm 13.88 /$ section in the control and treadmill exercise group, $361.00 \pm 20.44 /$ section in the rotenone-injected group, $420.70 \pm 9.78 /$ section in the rotenone-injected and treadmill exercise group. TPH expression in the dorsal raphe was decreased by injection of rotenone $(P<0.05)$ and treadmill exercise increased TPH expression in the rotenone-injected rats $(P<0.05)$.

\section{Effect of treadmill exercise on $5-\mathrm{HT}_{1 \mathrm{~A}}$ receptor expression in the dorsal raphe}

When the level of $5-\mathrm{HT}_{1 \mathrm{~A}}$ receptor $(50 \mathrm{kDa})$ in the control group was set at 1.00 , the level of $5-\mathrm{HT}_{1 \mathrm{~A}}$ receptor was $1.11 \pm$ 0.08 in the control and treadmill exercise group, $0.30 \pm 0.09$ in the rotenone-injected group, $0.96 \pm 0.20$ in the rotenone-injected
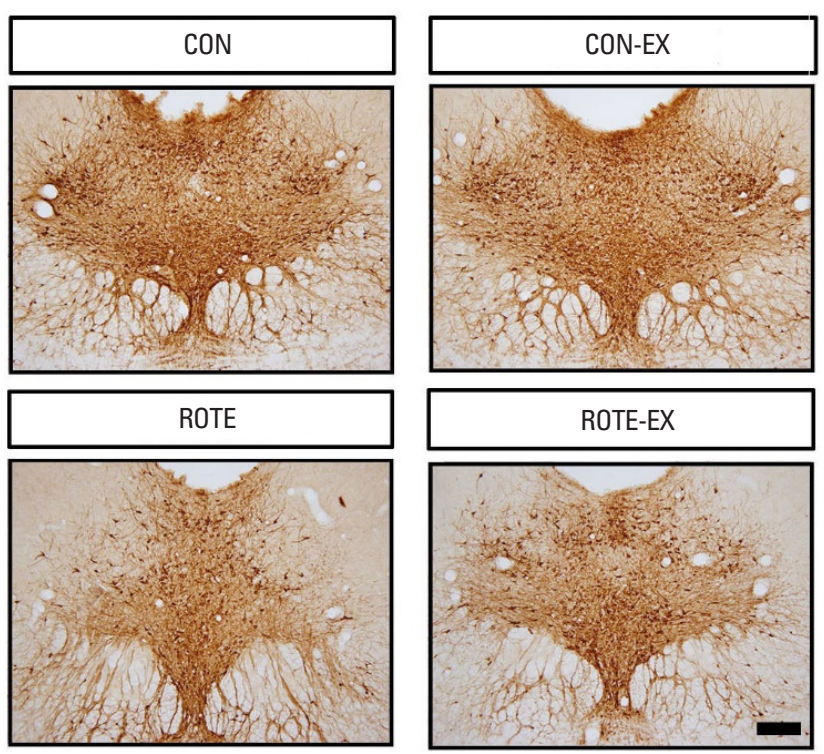

Fig. 3. Photomicrographs showing tryptophan hydroxylase (TPH) expressions in the dorsal raphe. The scale bar is $100 \mu \mathrm{m}$. CON, control group; CON-EX, control and treadmill exercise group; ROTE, rotenone-injected group; ROTE-EX, rotenone injected and treadmill exercise group.
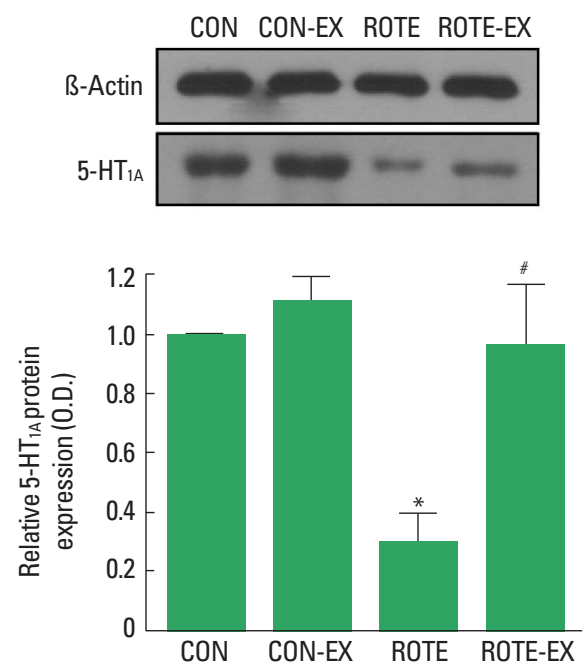

Fig. 4. Effect of treadmill exercise on 5-hydroxytryptamine-1A $\left(5-\mathrm{HT}_{1 \mathrm{~A}}\right)$ receptor expression in the dorsal raphe. Upper panel: Presentative $5-\mathrm{HT}_{1 \mathrm{~A}}$ expression. Lower panel: Relative $5-\mathrm{HT}_{1 \mathrm{~A}}$ expression in each group. CON, control group; CON-EX, control and treadmill exercise group; ROTE, rotenone-injected group; ROTE-EX, rotenone injected and treadmill exercise group. Data are presented as the means \pm standard error of the mean (SEM). ${ }^{*} P<0.05$ compared to the control group. ${ }^{\sharp} P<0.05$ compared to the rotenone-injected group.

and treadmill exercise group (Fig. 4). The expression of 5- $\mathrm{HT}_{1 \mathrm{~A}}$ were decreased by injection of rotenone $(P<0.05)$ and treadmill exercise increased $5-\mathrm{HT}_{1 \mathrm{~A}}$ expression in the rotenone-injected rats $(P<0.05)$. 


\section{DISCUSSION}

PD is closely associated with depression (Berghauzen-Maciejewska et al., 2014). FST is most commonly used test for assessment of depression in animal models of depression (Oitzl et al., 2000; Shin et al., 2017b). PD rats showed increased immobility time in FST (Shin et al., 2017b). In the present study, immobility time was increased and climbing time was decreased by rotenone injection and treadmill exercise suppressed immobility time and enhanced climbing time in the rotenone-injected rats. These results demonstrate that rotenone injection induced depressive state and treadmill exercise ameliorated this depressive state.

In the brain, serotonin cell bodies are located in the raphe nuclei of the brainstem, where they projected into the caudal brainstem and to the spinal cord (Hornung, 2003). Altered serotonergic neurotransmission contributes to the motor and non-motor features commonly associated with PD (Loane et al., 2013). Changes in the 5-HT system are associated with psychiatric disorders, including major depression and bipolar disorder (Fava and Kendler, 2000). Depressed patients showed lowered 5-HT concentration in the cerebrospinal fluid (Hou et al., 2006). Loss of tryptophan contents also increased symptom severity of depression patients, inducing downregulation of 5-HT biosynthesis (Ruhé et al., 2007). Antidepressant agents increased TPH expression as well as 5-HT synthesis (Shishkina et al., 2007; Yang et al., 2010). Dorsal raphe nuclei are involved in the anxiolytic effects of physical activity (Greenwood et al., 2005). In the present study, 5-HT and TPH expressions in the dorsal raphe were suppressed by rotenone injection and treadmill exercise increased the expressions of 5-HT and TPH in the rotenone-injected rats. These results demonstrate that rotenone induced 5-HT depletion in the dorsal raphe and treadmill exercise restored the content of 5-HT in the rotenone-induced PD rats.

Greenwood et al. (2005) reported that wheel running increased $5-\mathrm{HT}_{1 \mathrm{~A}}$ mRNA expression in dorsal raphe. 5- $\mathrm{HT}_{1 \mathrm{~A}}$ receptor is closely associated with depression and antidepressant effect (Cryan and Leonard, 2000). In the present study, 5- $\mathrm{HT}_{1 \mathrm{~A}}$ receptor was decreased by rotenone injection and treadmill exercise increased $5-\mathrm{HT}_{1 \mathrm{~A}}$ receptor expression in the rotenone-induced $\mathrm{PD}$ rats. These results demonstrate that rotenone down-regulated $5-\mathrm{HT}_{1 \mathrm{~A}}$ receptor in the dorsal raphe and treadmill exercise up-regulated $5-\mathrm{HT}_{1 \mathrm{~A}}$ receptor in the rotenone-induced $\mathrm{PD}$ rats.

In the present study, treadmill exercise ameliorated depressive symptoms in the rotenone-induced PD rats. The antidepressive effect of treadmill exercise might be ascribed to the enhancement of serotonergic function through upregulation of $5-\mathrm{HT}_{1 \mathrm{~A}}$ expression in the dorsal raphe.

\section{CONFLICT OF INTEREST}

No potential conflict of interest relevant to this article was reported.

\section{ACKNOWLEDGMENTS}

This work was supported by the National Research Foundation of Korea Grant funded by the Korean Government (NRF-2013S1A5A2A01018924).

\section{REFERENCES}

Aarsland D, Påhlhagen S, Ballard CG, Ehrt U, Svenningsson P. Depression in Parkinson disease--epidemiology, mechanisms and management. Nat Rev Neurol 2011;8:35-47.

Barnes NM, Sharp T. A review of central 5-HT receptors and their function. Neuropharmacology 1999;38:1083-1152.

Berghauzen-Maciejewska K, Kuter K, Kolasiewicz W, Głowacka U, Dziubina A, Ossowska K, Wardas J. Pramipexole but not imipramine or fluoxetine reverses the "depressive-like" behaviour in a rat model of preclinical stages of Parkinson's disease. Behav Brain Res 2014;271: 343-353.

Blesa J, Phani S, Jackson-Lewis V, Przedborski S. Classic and new animal models of Parkinson's disease. J Biomed Biotechnol 2012;2012:845618.

Boileau I, Warsh JJ, Guttman M, Saint-Cyr JA, McCluskey T, Rusjan P, Houle S, Wilson AA, Meyer JH, Kish SJ. Elevated serotonin transporter binding in depressed patients with Parkinson's disease: a preliminary PET study with [11C]DASB. Mov Disord 2008;23:1776-1780.

Brooks DJ, Pavese N. Imaging biomarkers in Parkinson's disease. Prog Neurobiol 2011;95:614-628.

Christiansen L, Tan Q, Iachina M, Bathum L, Kruse TA, McGue M, Christensen K. Candidate gene polymorphisms in the serotonergic pathway: influence on depression symptomatology in an elderly population. Biol Psychiatry 2007;61:223-230.

Cryan JF, Leonard BE. 5-HT1A and beyond: the role of serotonin and its receptors in depression and the antidepressant response. Hum Psychopharmacol 2000;15:113-135.

Fava M, Kendler KS. Major depressive disorder. Neuron 2000;28:335-341.

Graeff FG. Serotonergic systems. Psychiatr Clin North Am 1997;20:723739.

Greenwood BN, Foley TE, Day HE, Burhans D, Brooks L, Campeau S, 
Fleshner M. Wheel running alters serotonin (5-HT) transporter, 5-HT1A, 5-HT1B, and alpha 1b-adrenergic receptor mRNA in the rat raphe nuclei. Biol Psychiatry 2005;57:559-568.

Hornung JP. The human raphe nuclei and the serotonergic system. J Chem Neuroanat 2003;26:331-343.

Hou C, Jia F, Liu Y, Li L. CSF serotonin, 5-hydroxyindolacetic acid and neuropeptide $\mathrm{Y}$ levels in severe major depressive disorder. Brain Res 2006;1095:154-158.

Kish SJ, Tong J, Hornykiewicz O, Rajput A, Chang LJ, Guttman M, Furukawa Y. Preferential loss of serotonin markers in caudate versus putamen in Parkinson's disease. Brain 2008;131(Pt 1):120-131.

Leitch MM, Ingram CD, Young AH, McQuade R, Gartside SE. Flattening the corticosterone rhythm attenuates 5-HT1A autoreceptor function in the rat: relevance for depression. Neuropsychopharmacology 2003; 28:119-125.

Loane C, Wu K, Bain P, Brooks DJ, Piccini P, Politis M. Serotonergic loss in motor circuitries correlates with severity of action-postural tremor in PD. Neurology 2013;80:1850-1855.

Lucki I. The spectrum of behaviors influenced by serotonin. Biol Psychiatry 1998;44:151-162.

Neumeister A, Nugent AC, Waldeck T, Geraci M, Schwarz M, Bonne O, Bain EE, Luckenbaugh DA, Herscovitch P, Charney DS, Drevets WC. Neural and behavioral responses to tryptophan depletion in unmedicated patients with remitted major depressive disorder and controls. Arch Gen Psychiatry 2004;61:765-773.

Oitzl MS, Workel JO, Fluttert M, Frösch F, De Kloet ER. Maternal deprivation affects behaviour from youth to senescence: amplification of individual differences in spatial learning and memory in senescent
Brown Norway rats. Eur J Neurosci 2000;12:3771-3780.

Roy A, Nielsen D, Rylander G, Sarchiapone M, Segal N. Genetics of suicide in depression. J Clin Psychiatry 1999;60 Suppl 2:12-17.

Ruhé HG, Mason NS, Schene AH. Mood is indirectly related to serotonin, norepinephrine and dopamine levels in humans: a meta-analysis of monoamine depletion studies. Mol Psychiatry 2007;12:331-359.

Savitz J, Lucki I, Drevets WC. 5-HT(1A) receptor function in major depressive disorder. Prog Neurobiol 2009;88:17-31.

Shin MS, Kim TW, Lee JM, Ji ES, Lim BV. Treadmill exercise alleviates nigrostriatal dopaminergic loss of neurons and fibers in rotenone-induced Parkinson rats. J Exerc Rehabil 2017a;13:30-35.

Shin MS, Park SS, Lee JM, Kim TW, Kim YP. Treadmill exercise improves depression-like symptoms by enhancing serotonergic function through upregulation of 5-HT1A expression in the olfactory bulbectomized rats. J Exerc Rehabil 2017b;13:36-42.

Shishkina GT, Kalinina TS, Dygalo NN. Up-regulation of tryptophan hydroxylase-2 mRNA in the rat brain by chronic fluoxetine treatment correlates with its antidepressant effect. Neuroscience 2007;150:404412.

Strawbridge WJ, Deleger S, Roberts RE, Kaplan GA. Physical activity reduces the risk of subsequent depression for older adults. Am J Epidemiol 2002;156:328-334.

Varçin M, Bentea E, Michotte Y, Sarre S. Oxidative stress in genetic mouse models of Parkinson's disease. Oxid Med Cell Longev 2012;2012: 624925.

Yang FZ, Wu Y, Zhang WG, Cai YY, Shi SX. Estradiol or fluoxetine alters depressive behavior and tryptophan hydroxylase in rat raphe. Neuroreport 2010;21:309-312. 